\title{
LLNL Small-Scale Static Spark Machine: Static Spark Sensitivity Test
}

\author{
L. R. Simpson, M.F. Foltz
}

August 23, 1999

U.S. Department of Energy

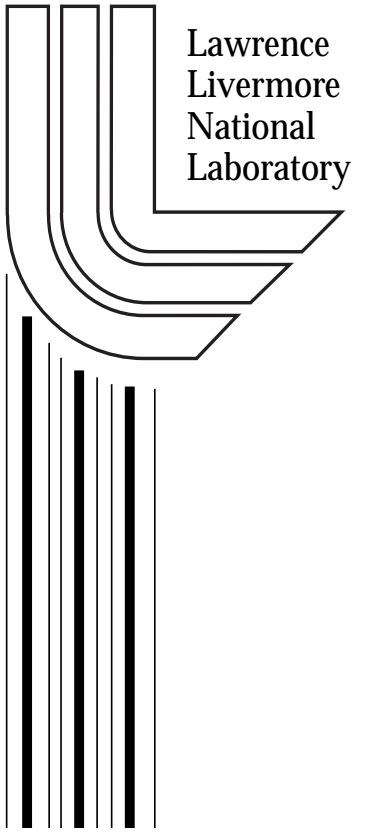




\section{DISCLAIMER}

This document was prepared as an account of work sponsored by an agency of the United States Government. Neither the United States Government nor the University of California nor any of their employees, makes any warranty, express or implied, or assumes any legal liability or responsibility for the accuracy, completeness, or usefulness of any information, apparatus, product, or process disclosed, or represents that its use would not infringe privately owned rights. Reference herein to any specific commercial product, process, or service by trade name, trademark, manufacturer, or otherwise, does not necessarily constitute or imply its endorsement, recommendation, or favoring by the United States Government or the University of California. The views and opinions of authors expressed herein do not necessarily state or reflect those of the United States Government or the University of California, and shall not be used for advertising or product endorsement purposes.

Work performed under the auspices of the U. S. Department of Energy by the University of California Lawrence Livermore National Laboratory under Contract W-7405-Eng-48.

This report has been reproduced directly from the best available copy.

Available to DOE and DOE contractors from the

Office of Scientific and Technical Information

P.O. Box 62, Oak Ridge, TN 37831

Prices available from (423) 576-8401

http://apollo.osti.gov/bridge/

Available to the public from the National Technical Information Service

U.S. Department of Commerce 5285 Port Royal Rd., Springfield, VA 22161 http://www.ntis.gov/

OR Lawrence Livermore National Laboratory Technical Information Department's Digital Library http://www.llnl.gov/tid/Library.html 


\section{LLNL Small-Scale Static Spark Machine: Static Spark Sensitivity Test}

L. Richard Simpson, M. Frances Foltz

Lawrence Livermore National Laboratory

FF:nm/Q2421 


\begin{abstract}
Small-scale safety testing of explosives and other energetic materials is done in order to determine their sensitivity to various stimuli, such as friction, static spark, and impact. Typically this testing is done to discover potential handling problems that may exist for either newly synthesized materials of unknown behavior, or materials that have been stored for long periods of time. This report describes the existing "Static Spark Test Apparatus" at Lawrence Livermore National Laboratory (LLNL), as well as the method used to evaluate the relative static spark sensitivity of energetic materials. The basic design, originally developed by the Picatinny Arsenal in New Jersey, is discussed. The accumulated data for the materials tested to date is not included here, with the exception of specific examples that have yielded interesting or unusual results during the tests.
\end{abstract}

\title{
Introduction
}

High explosives are divided into two classes: initial detonating (or primary) and noninitiating (or secondary explosives). The primary explosives are extremely sensitive to ignition by heat, shock and electrical discharge - the secondary explosives are not. ${ }^{(1)}$ Most explosives used within the Department of Energy (DOE) complex are secondary explosives, and by definition are insensitive to electrostatic discharge. In addition, a subset of these explosives are the plastic-bonded explosives (PBXs). Like other polymeric materials, they are in fact good electrical insulators and therefore not easy to initiate electrically. ${ }^{(2)}$

Nevertheless, the threat of accidental initiation by lightening or electric spark make it desirable to subject new formulations to electrostatic spark sensitivity testing. A method is needed to evaluate the static spark sensitivity of explosives over an electrostatic discharge range relevant for handling scenarios. By evaluating the relative sensitivity of the explosives to well-defined stimuli, a degree of handling safety of the material can be inferred by experts familiar with the test procedure and data.

LLNL maintains a database of sensitivity results for new (experimental) and standard explosives that have been or are in use in the DOE complex. The existing test apparatus (LLNL Static Spark Machine) is based on a design developed by the Picatinny Arsenal in New Jersey to evaluate electrostatic spark sensitivity of primary explosives ${ }^{(3)}$ By varying capacitance and resistance of the circuitry, the machine is designed to simulate the static electric energy output of the human body. 
Modifications of the original design began in 1978. The earliest testing with the first LLNL system began in 1980. This first design involved testing explosives with no series resistor in the discharge circuit. As a result, reactions (events) were easily observed in tests with discharges as low as 0.1 joule $(\mathrm{J})$ or less. These results nevertheless did not necessarily indicate the explosive in question required special attention. It was decided that the relationship of these test results to real handling hazards was obscure.

A procedural and equipment redesign was carried out in $1989^{(4)}$ The resulting modification standardized the test to discharge one joule of energy from the capacitors, inserting a 510-ohm resistor in series with the moving electrode. Ten trials at this level constitutes a test, with no reactions in ten trials ( 0 in $10 @ 1.0$ joule) warranting the designation of "insensitive" for the material. If any event is detected in ten trials, then testing proceeds until a level is found where ten trials results in no events. A material is considered sensitive if it gives a one-in-ten reaction at or below 0.25 joule. Events observed at the 0.1 joule level require the explosive be treated as electrically sensitive and handled as such according to Department of Energy (DOE) Safety Regulations. Procedures appropriate for this designation (conductive wrist straps, shoes, table, etc) would have to be followed.

Since all testing after November 1989 has been carried out with the modified design, apparent discrepancies in the results before and after this date are very likely due to the change in procedure.

\section{Spark Test Description}

Static electricity sensitivity tests are used to determine the electrostatic hazards associated with the handling of explosives. There is no single standard static electricity test. Those tests in use have been typically independently designed and constructed by each facility for internal use. Since the equipment are often different, a range of different minimum reaction limits can be determined for the same explosive, often with different relative sensitivity rankings for a given set of explosives.

One of a standard set of small-scale sensitivity tests used for explosives at LLNL is the Spark Sensitivity Test. The purpose of the test is to determine the spark sensitivity of small (3to 5-mg) samples of explosives and other energetic materials. A sample of the test explosive is sealed into a plastic ring attached to a steel disk, and voltage discharged through the sample. 
Evidence of reaction is judged from the condition of the Mylar tape placed over the sample through which the voltage had been discharged. The voltage, capacitance and resistance can be adjusted to achieve the output energy desired. The results obtained are expressed as a zero-in-ten or one-in-ten reaction at a specified voltage and discharge energy (J).

The adopted test criteria mocks up about a factor of ten times more energy than that released by a "standard" fully charged human. Ten trials at that level constitute a test. No reactions in ten trials would allow the explosive be designated "insensitive". If any event is detected in the ten trials, the testing proceeds to lower levels until ten trial results in no events.

\section{Apparatus}

The machine consists of three parts: the capacitor bank and charging system; voltage meter; and discharge mechanism (see Figure 1). The capacitor bank and charging system, or Spark Gap Power Supply (LLNL drawing LEA78-1602), is housed in a metal box below the enclosed discharge mechanism. jumpers on the front of the box allow the capacitance to be varied as needed. The capacitance levels available are: 50, 200, 500, 2000, 5000 and 20,000 pF. A splitter box is available to double any of these values. The voltage control, reset and on-off buttons are also on the front of the box. The voltage range is 0 to 10,000 static volts $(10 \mathrm{~W})$. Energy output is up to $2 \mathrm{~J}(40,000 \mathrm{pF}$ at $10 \mathrm{~W})$. The voltage output is connected to an external static volt meter that reads zero to ten thousand static volts $(10 \mathrm{~W})$. See Table I for discharge information at standard operating condition of $20,000 \mathrm{pF}$, as well as the less commonly used 40,000, 1000 and $500 \mathrm{pF}$.

The discharge mechanism is housed in a Lucite ${ }^{\mathrm{TM}}$ containment box placed on top of the capacitor box. The mechanism consists of a vertical plunger assembly with a pin vice holder on the bottom end attached to a spring-loaded scissors link. A steel phonograph needle is held in the holder (see Figure 2). The plunger assembly is connected by a wire to the capacitor bank through a series of resistors so the resistance can be changed as desired. Although three values are available $(0,51$, and $510 \mathrm{ohm})$, the resistance is usually set at $510 \mathrm{ohm}$. A horizontal bar, which passes through the side of the containment box, connects to the scissors link and spring. It has a simple tripping mechanism on the outside of the box. Below the plunger system is a fixture for holding the sample disk. It is mounted through the bottom of the Lucite TM containment box on a large adjustment wheel. The wheel is turned to adjust the gap between the phonograph needle and sample disk, normally set at 0.007 inch. 
The sample disks consist of two parts: a steel disk -0.750-inch diameter and -0.300-inch thick, and a plastic ring to contain the sample. A series of disks is measured to find ten the same thickness. This ring is held by adhesive to the steel disk. A 3- to 5-mg sample of explosive is loaded into the ring with a spatula and the leveled off. A piece of 0.002-inch thick Mylar ${ }^{\mathrm{TM}}$ tape is then placed over the top of the sample and pressed down to seal the sample in the ring.

The voltage meter is an Electronic Instrument Service analog electrostatic volt meter (Model ESH-2, S/N ES9633). The capacitor bank and charging system is an LLNL built Spark Gap Power Supply (LLNL drawing LEA78-1602).

\section{Pretest Procedure}

No attempt is made to condition the explosives unless they are known to be unusually hygroscopic. Storage in the test lab for an hour or so is considered acceptable for most explosives. Samples known to be hygroscopic are kept in a desiccator until needed. The building housing the test equipment has its temperature controlled to $68 \pm 3^{\prime} \mathrm{F}\left(1^{\prime} \mathrm{C}\right.$ ). Building humidity is not controlled, ranging from a very low 10 percent relative humidity to $\sim 80$ percent.

Ten samples are normally used in a test. Test sample holders consist of a steel disk, 0.300 -inch thick by 0.75 -inch diameter. The disks are measured and a set of ten, all the same height, is assembled. A small plastic ring with adhesive on one side is applied to the top of the steel disks approximately in the center. A sample of the test explosive is placed in the ring and a piece of 0.002-inch Mylar ${ }^{\mathrm{TM}}$ tape is applied to the top of the ring to seal the explosive into the ring. Powders instead of pressed samples are normally tested, but rubberized materials can be tested as pieces. Liquids can be tested but the standard sample holder makes it impractical on a routine basis.

\section{Procedure}

The LLNL static spark test is used for two purposes. First, it is one of several small-scale safety tests used to determine whether a material may or may not be safely handled if reasonable care is exercised. Second, it is used to compare the relative spark sensitivities of various explosive materials. High precision is unnecessary in the first case, so the procedure 
can be varied to suit the nature of the test explosive. Tests of the second type are done according to a strict routine by the specific steps are outlined in Appendix A.

A steel disk (with no plastic ring attached) is placed in the holding fixture. The needle is adjusted to its lowest position and the gap between the needle and steel disk is corrected with a 0.007-inch "feeler" gauge. With the needle assembly cocked, a steel disk with sample loaded is placed in the holding fixture and the Lucite ${ }^{\mathrm{TM}}$ door closed. The door is interlocked with the power so that the operator cannot come in contact with high voltage while handling samples in the containment box. A red light on the top right corner of the box is lit when the interlock is completed. The charging system is powered up and charge increased to the desired level.

Normally, the testing is begun at $10 \mathrm{M}$ The needle assembly is tripped by pushing the trigger button, which releases the needle assembly. This causes the phonograph needle to pierce the Mylar ${ }^{\mathrm{TM}}$ tape on the sample disk and discharge the electric charge through the sample.

Upon removing the sample disk, the condition of the tape is noted and recorded. If the result is a "Go" twice at the same voltage before ten tests are completed, the voltage is reduced according to the chart in the workbook (see Figure 3). If not, the test is continued until a onein-ten result is obtained (or a zero-in-ten at $10 \mathrm{kV}$ ). Appendix B is a troubleshooting guide to address potential problems with testing.

\section{Data Interpretation and Evaluation}

A test is considered to be a "Go" if the Mylar ${ }^{\mathrm{TM}}$ tape is ruptured, resulting in a hole larger than the needle alone makes. A "No-Go" is the result if the tape shows only the tiny puncture from the needle. See Figure 4 for examples Mylar ${ }^{\mathrm{TM}}$ tape after "Go" and "No-Go" tests. These definitions were derived from actual testing of many samples to produce as wide a range of different tape ruptures.

Results are reported in kilovolts (W) and joules G). A material is considered spark sensitive if it has a one-in-ten reaction at or below 0.25 joules.

\section{Calibration Procedure}

No calibration of the apparatus is necessary, with the exception of a periodic calibration of the volt meter, and verification that all the steel disks used are of the same thickness. 


\section{Examples}

The following explosives representative of those standard explosives often handled in the DOE community. They are all secondary explosives, and have all been shown to be electrostatic spark insensitive using the current design of the LLNL Static Spark Test Apparatus.

\begin{tabular}{|l|c|}
\hline High Explosive & LLNL Test Results \\
\hline Comp B-3 & 0 in 10 @ 1.0 joule \\
\hline FEFO & " \\
\hline HMX & " \\
\hline HNS & " \\
\hline LX-04 & " \\
\hline LX-07 & " \\
\hline LX-10 & " \\
\hline LX-11 & " \\
\hline LX-16 & " \\
\hline LX-17 & " \\
\hline PBX 9404 & " \\
\hline PBX 9407 & PBX 9501 \\
\hline PBX 9502 & \\
\hline PETN & \\
\hline
\end{tabular}

In addition, PBX 9502 was also tested with the original LLNL test apparatus before the series resistor was inserted into the circuit. This test environment was more severe than that currently employed. The testing yielded a 0 -in- 10 response at 0.25 joule, which categorized this explosive as spark insensitive. 
CODTU-99-0512

Page 8 of 15

\section{Acknowledgments}

The authors would like to thank LeRoy Green for valuable input with his extensive knowledge of small-scale testing. This work was performed under the auspices of the U.S. Dept. of Energy by Lawrence Livermore National Laboratory under contract No. W-7405-ENG-48.

\section{References}

1) Dobratz, B.M., Crawford, P.C., "LLNL Explosives Handbook: Properties of Chen-dcal Explosives and Explosive Simulants," Report UCRL-52997 (Change 2), Lawrence Livermore National Laboratory, Livermore CA (January 31, 1985).

2) Dobratz, B.M. et al., "The Sensitivity of Trian-dnotrinitrobenzene (TATB) and TATB Formulations: Summary Report," Report UCID-17808, Lawrence Livermore Laboratory, Livermore CA (September 1978).

3) (a) Kirschenbaum, M.S., Electrostatic Sensitivity of Explosives as a Function of Circuit Parameters, Proceedings of the DAE-AF-F/G-7304 Technical Meeting, 29 April - 1 May 1974, Naval Surface Weapons Center, Silver Spring, MD: (b Kirschenbaum, M.S., Technical Report 4955, Response of Primary Explosives to Gaseous Discharges in an Improved Approaching-Electrode Electrostatic Sensitivity Apparatus, Picatinny Arsenal, Dover, NJ (October 1976): (c) Westgate, C.R., Kirschenbaum, M.S., and Pollock, B.D., Electrical and Photographic Characterization of Low-Intensity Capacitor Spark Discharges, Technical Report 4737, Picatinny Arsenal, Dover NJ (February 1975).

4) Memo from LeRoy Green and Gordon Moody, "Electrical Sensitivity Test Method and Significance," Lawrence Livermore National Laboratory, Livermore CA (Nov. 10, 1989).

5) Explosive Hazard Assessment Manual of Tests: Test No. 6/66, The Electric Spark Test, Sensitiveness Collaboration Committee Explosives Research and Development Establishment, Procurement Executive Ministry of Defense, Waltham Abbey, Essex, England, 1966.

6) Brown, F.W., Kusler, D.J., and Gibson, F.C., Sensitivity of Explosives to Initiation by Electrostatic Discharges, Report of Investigations 5002, Bureau of Mines (September 1953). 
7) Joint Service Safety and Performance Manual for Qualification of Explosives for Military Use, joint Technical Coordinating Group for Air Launched Non-Nuclear Ordinance Working Party for Explosives, Picatinny Arsenal, Dover, NJ, 1971.

Table I - Standard and Non-Standard Conditions

\begin{tabular}{|c|c|c|c|c|}
\hline \multirow[b]{2}{*}{$\mathbf{k V}$} & \multirow{2}{*}{$\begin{array}{l}\text { standard (1) } \\
20,000 \mathrm{pF}\end{array}$} & \multicolumn{3}{|c|}{ less commonly used conditions $(J)$} \\
\hline & & $40,000 \mathrm{pF}$ & $1000 \mathrm{pF}$ & $500 \mathrm{pF}$ \\
\hline 10.0 & 1.00 & 2.05 & 0.05 & 0.025 \\
\hline 9.5 & 0.90 & 1.81 & 0.045 & 0.022 \\
\hline 9.0 & 0.81 & 1.62 & 0.040 & 0.020 \\
\hline 8.5 & 0.72 & 1.45 & 0.036 & 0.018 \\
\hline 8.0 & 0.64 & 1.28 & 0.032 & 0.016 \\
\hline 7.5 & 0.56 & 1.13 & 0.028 & 0.014 \\
\hline 7.0 & 0.49 & 0.98 & 0.024 & 0.012 \\
\hline 6.5 & 0.42 & 0.85 & 0.021 & 0.010 \\
\hline 6.0 & 0.36 & 0.72 & 0.018 & 0.009 \\
\hline 5.5 & 0.30 & 0.61 & 0.015 & 0.007 \\
\hline 5.0 & 0.25 & 0.50 & 0.012 & 0.006 \\
\hline 4.5 & 0.20 & 0.41 & 0.010 & 0.005 \\
\hline 4.0 & 0.16 & 0.32 & 0.008 & 0.004 \\
\hline 3.5 & 0.12 & 0.25 & 0.006 & 0.003 \\
\hline 3.0 & 0.09 & 0.18 & 0.004 & 0.002 \\
\hline 2.5 & 0.06 & 0.13 & 0.003 & 0.0015 \\
\hline 2.0 & 0.04 & 0.08 & 0.002 & 0.001 \\
\hline
\end{tabular}




\section{Appendix A - Detailed Procedure (see Figures $1 \& 2$ )}

1) Insert a bare steel disk in the holding fixture.

2) Pull the cocking rod until the scissors link is straight and the needle is at its lowest position.

3) Using a 0.007-inch feeler gage, adjust the gap between the needle and steel disk by turning the large adjustment wheel beneath the box.

4) A plastic ring is applied to the top of each steel disk, centered visually.

5) An explosive sample (usually a powder) is placed in the ring with a spatula.

6) Apply a piece of 0.002-inch Mylar TM tape to the top of the rings to seal in the sample.

7) Turn on the power by pushing in the power button.

8) Cock the tripping mechanism by pulling on the cocking rod on the left side of the containment box.

9) Push up on the bottom of the tripping button to lock the rod.

10) Place a loaded disk in the holding fixture under the needle inside the containment box. Close the door to the containment box.

11) Make sure the power control knob is turned down to zero. Press the reset button on the front of the control panel to allow the capacitor bank to be charged.

12) Turn the power knob to charge the capacitor bank to the desired voltage.

13) Push down on the tripping button to release the scissors link, thereby piercing the Mylar $^{\mathrm{TM}}$ tape and discharging the capacitor bank through the sample.

14) Open the door to the containment box and remove the disk.

15) Observe the condition of the tape and record the observation in the workbook.

16) Repeat steps 8 through 14 until a one-in-ten result is achieved '. If the testing results in two "Go"s" before ten tests are completed, reduce the voltage according to the chart in the workbook (see Figure 4). If the test results in a zero-in-ten at $10 \mathrm{~W}$, that is acceptable also.

17) Make a copy of the results and give it to the requester. Make a file copy for the Static Spark data binder. 


\section{Appendix B - Troubleshooting Guide}

\begin{tabular}{|l|l|l|}
\hline Problem & Probable Cause(s) & Solution \\
\hline $\begin{array}{l}\text { Capacitors do not } \\
\text { discharge when needle is }\end{array}$ & $\begin{array}{l}\text { Micro-switches may be } \\
\text { maladjusted. }\end{array}$ & $\begin{array}{l}\text { Have electronic technician } \\
\text { inspect and adjust micro } \\
\text { switches. }\end{array}$ \\
\hline Capacitors do not charge. & $\begin{array}{l}\text { Operator did not push } \\
\text { reset button, discharge } \\
\text { mechanism is not cocked } \\
\text { or micro-switches are } \\
\text { maladjusted. }\end{array}$ & $\begin{array}{l}\text { Have electronic technician } \\
\text { inspect wiring and micro } \\
\text { switches and make repairs } \\
\text { and/or adjustments. Make } \\
\text { sure operator has cocked } \\
\text { discharge mechanism and } \\
\text { has pressed the reset } \\
\text { button before trying to } \\
\text { charge. }\end{array}$ \\
\hline $\begin{array}{l}\text { Sporadic or erratic } \\
\text { behavior. }\end{array}$ & $\begin{array}{l}\text { Capacitors are probably } \\
\text { dirty, causing arcing. }\end{array}$ & $\begin{array}{l}\text { Have electronic technician } \\
\text { clean capacitors. }\end{array}$ \\
\hline
\end{tabular}




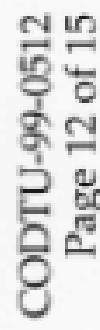

$\frac{\mathscr{g}}{9}$

है
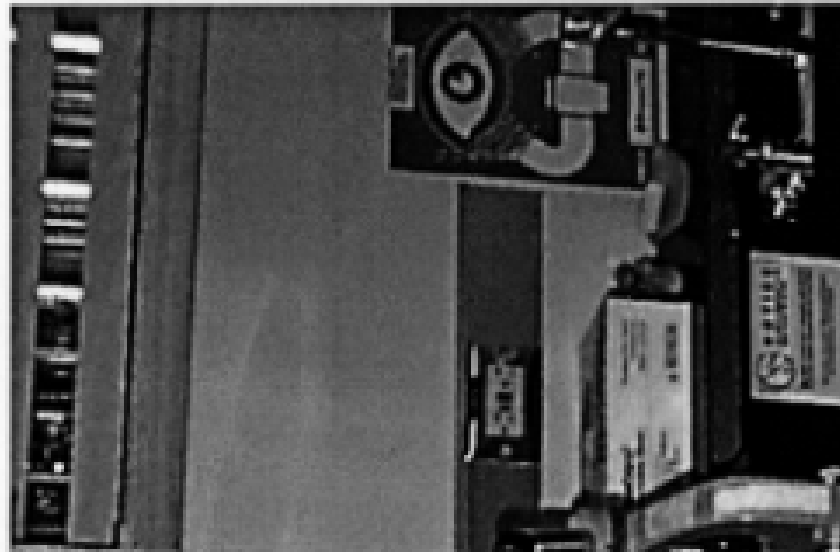

I

है

हू

苑

흠
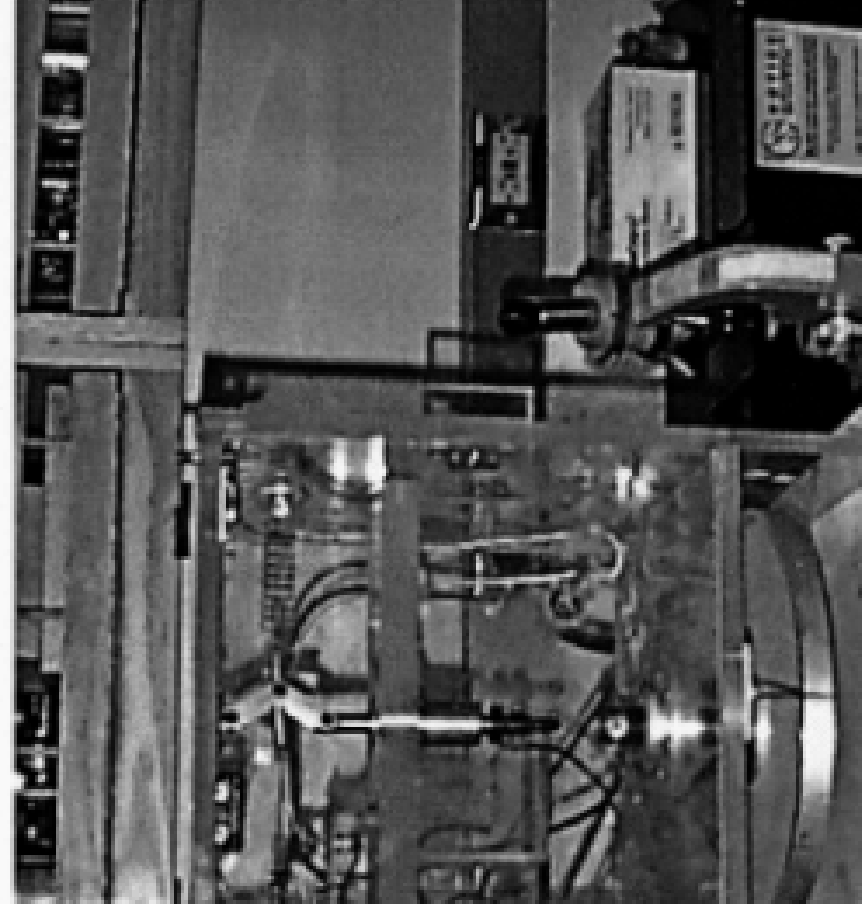
Figure 2 - A steel phonograph needle is held in the brass holder above the sample.

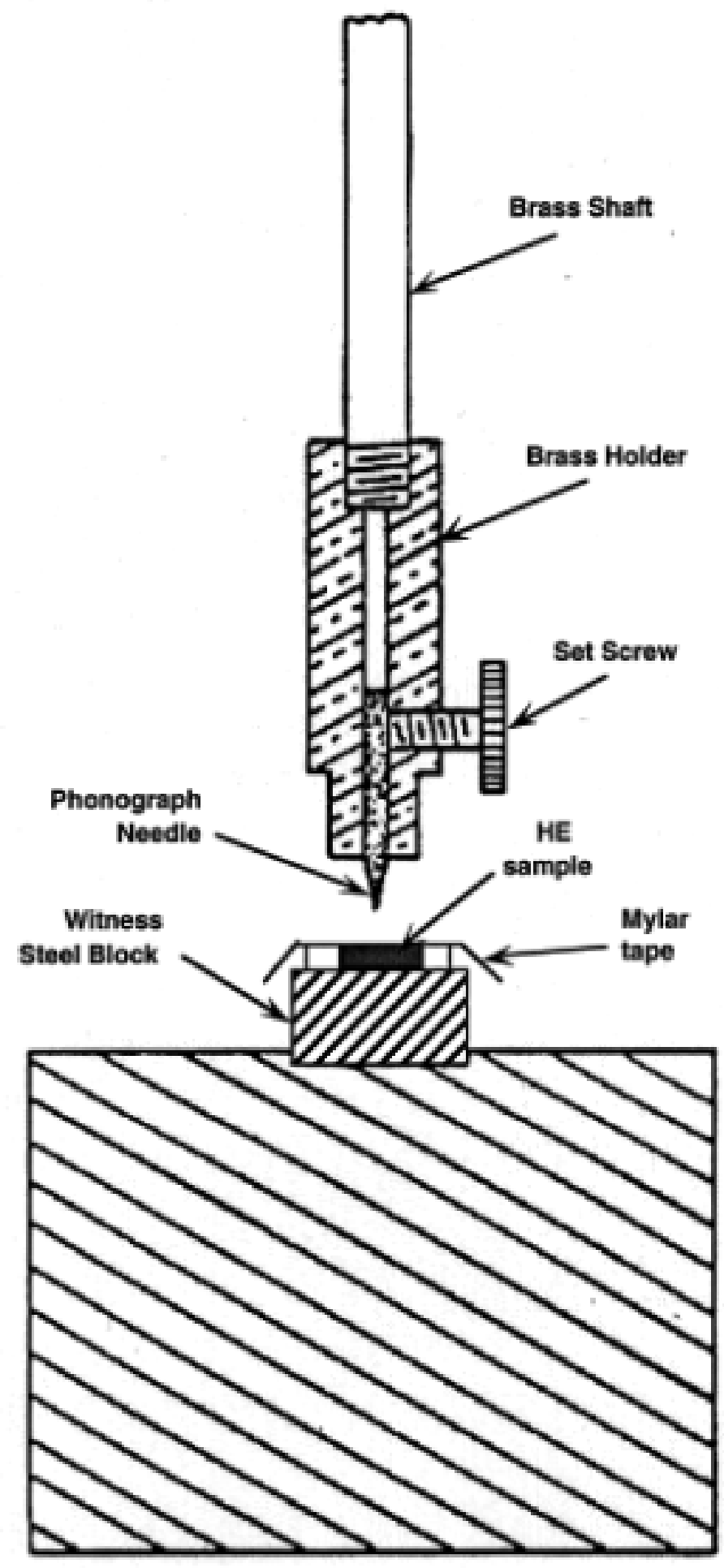


CODTU-99-0512

Page 14 of 15

Figure 3 - Examples of typical test data obtained in the "shorted" mode. After the 1989 insertion of the 510-ohm resistor in series, almost no "Go's" have been observed.

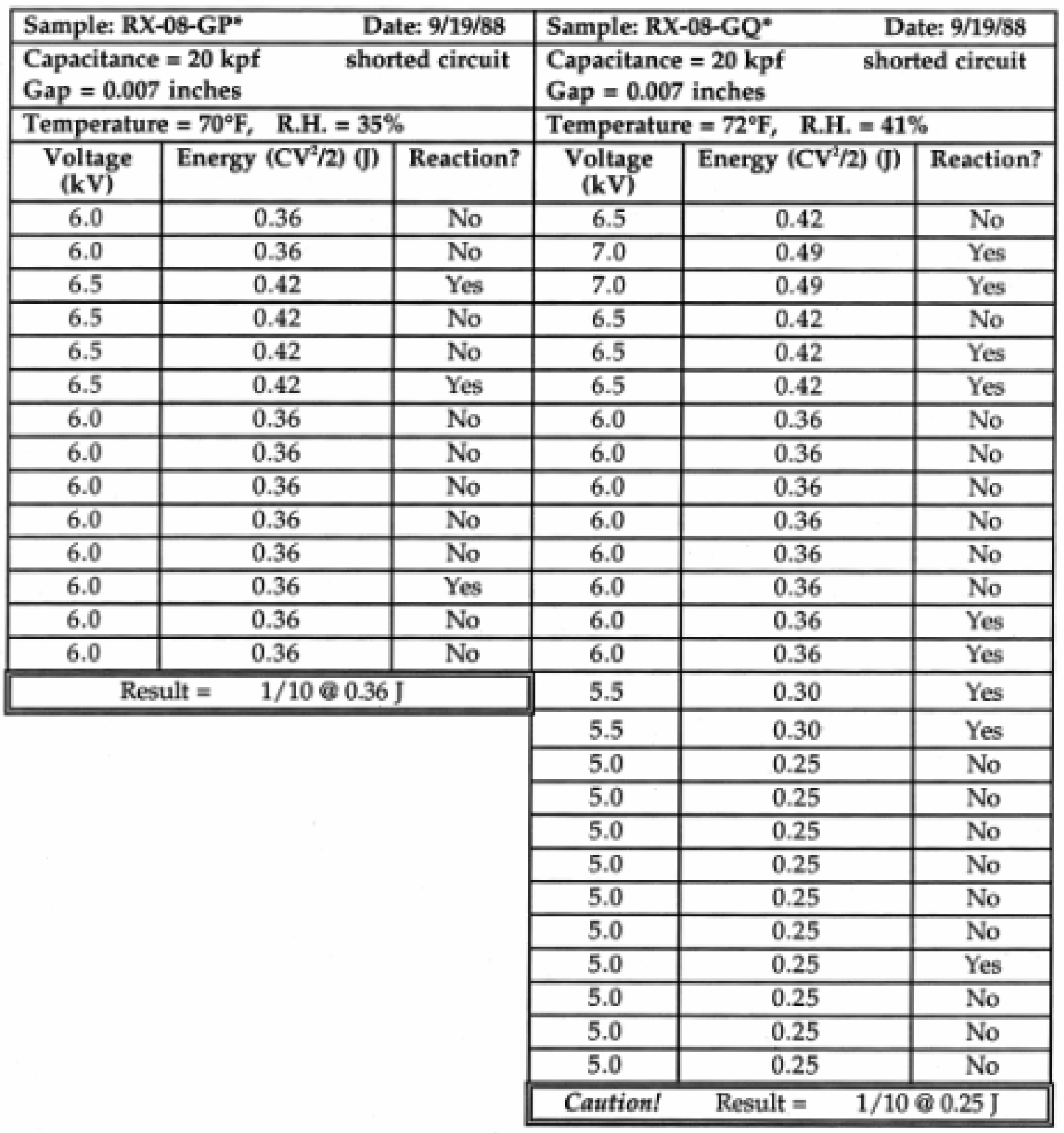

- RX-08-GP is an explosive mixture: $60 \% \mathrm{HMX} / 13.3 \% \mathrm{TA} / 24 \% \mathrm{PEG} / 2.66 \% \mathrm{~N}-100$

** RX-08-GQ is an explosive mixture: $60 \%$ HMX/25.45\% TA/13.09\% PEG/1.45\% N-100 
Figure 4 - Examples Mylar" tape after "Go" and "No-Go" tests (shorted condition).

\begin{tabular}{|c|c|c|c|c|}
\hline Material & $\begin{array}{c}\text { Test Date / } \\
\text { Shot \# } \\
\end{array}$ & $\begin{array}{c}\text { Voltage/ } \\
\text { Capacitance }\end{array}$ & $\begin{array}{c}\text { Response } \\
(\mathrm{Go} / \mathrm{No} \mathrm{Go})\end{array}$ & Mylar Tape after Test \\
\hline PETN * & $\begin{array}{l}8 / 27 / 80 \\
\text { Shot \#6 }\end{array}$ & $\begin{array}{l}3.2 \mathrm{kV} \\
0.05 \mu \mathrm{F}\end{array}$ & No Go & \\
\hline 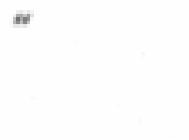 & $\begin{array}{l}8 / 27 / 80 \\
\text { Shot \#4 }\end{array}$ & $\begin{array}{l}3.2 \mathrm{kV} \\
0.05 \mu \mathrm{F}\end{array}$ & Go & \\
\hline " & $\begin{array}{l}8 / 27 / 80 \\
\text { Shot } \# 3\end{array}$ & $\begin{array}{l}3.4 \mathrm{kV} \\
0.05 \mu \mathrm{F}\end{array}$ & Go & \\
\hline " & $\begin{array}{l}8 / 22 / 80 \\
\text { Shot \#34 }\end{array}$ & $\begin{array}{l}8.0 \mathrm{kV} \\
0.05 \mu \mathrm{F}\end{array}$ & Goll N.H.O. & \\
\hline N & $\begin{array}{l}8 / 27 / 80 \\
\text { Shot \#12 }\end{array}$ & $\begin{array}{l}9.0 \mathrm{kV} \\
0.05 \mu \mathrm{F}\end{array}$ & $\begin{array}{l}\text { Go!! Violent } \\
\text { But Not H.O. }\end{array}$ & \\
\hline " & $\begin{array}{l}8 / 27 / 80 \\
\text { Shot \#13 }\end{array}$ & $\begin{array}{l}9.5 \mathrm{kV} \\
0.05 \mu \mathrm{F}\end{array}$ & H.O. & No tape left \\
\hline
\end{tabular}

* LLNL lot B-509, Trojan-made

N.H.O. $=\mathrm{A}$ "Go" reaction that is Not High Order.

H.O. $=$ High Order 